\title{
The Substance of Procedure: NON-PARTY DISCLOSURE IN THE CANADIAN AND U.S. ONLINE MUSIC SHARING LITIGATION
}

\author{
JANE BAILEY
}

The music recording industry is stuing Internet swbscribers in Canada and the United States for alleged copyright infringement in unprecedented numbers. The procedure for obtaining non-parng disclosure has taken on rene'ucd significance in this context, as the indusing reques/s disclosure of identifying and private information from Internet Sorvice Providers (ISPs) who provide online communicators with their Internet connections. legislative measures adopled in the U.S. expedited the disclosure process through an administrative mechanism will fow' threshold requirements for issuance of a subpoena agoinst an ISP. In Canada (and affer late 2004 in the U.S.). disclosure reguesis proceeded under federal rules of court. Comparison of the expedifed administrative and the judicially interprofed rules-based processes roises importam questions about the connection bifucen procedure and substance, and procedural justice more generally: Nof only are more permissive rules for disclosure oficn inconsistent with protecting substantive rights, such as privucy, but they also cannot be presumed to enhunce the likelihood of achieving accurate substantive legol outcomes. If non-party disclosure rules are not contextually designed and implemented wo reflect the power and resource imbalance berwecn the plainsiff music industry and the individual defendan's pursuct in online music sharing litigation. the public and private interest in substantive adjudication of critical questions relating to copyright law may be foreclosed for reasons wholly umrelated to substantive legal merits.
Le secteur de l'inregistrement de musique poursuil less abonnes a Iniernet an Canada et anu Etats-linis pour violation presume'c. en nombre incigale, dedroils d'meter. La procidure d obicnion d "ume diwigation de tiers a pris une signification renowelc't dans ce contexte. I'industrie' demandant $d e$ divwlguer les renscignements privés c't permettant didentifier les fournisseurs de senvices Internet (SS) qui offremt dex communicateurs en lighe ave les connexions Intomet. Des mesures tégislatives adoptés and Elosts-Unis ont permis d'accilerer la procedure de divilganion an moven din mecanisme administratif alomt des exigences de seuil has pour f'imission d'un' assignations is finoigner contre tun ISP. Au Canada (et apris la fin de 2004 aur Etats-Cinis). les demandes de divulgation somf faikes conformemem aux règles des cours fédirales. La comparaison de la procédure administrative accélérée et des procédurcs basées sur les règles inicrprítées par la magistrature sonlève d'imporranses questions sur le lien entre la forme ef le fond et sur la justice en matière de procidure en général. Les righles de divtgation phus permissives manquent souvent de cohirence pour proteger les droits importants comme le droit du respect de la vie prived. "t elles $n$ 'augmentem pas les chances d'oblemir des résullats juridiques pricis imporsants. Si les reggles de divulgation de tiers ne sont pas conswes en fonction du contexte' et mises en aure de manicre a refleter le pouroir ef le déséquilibre entre le sc'ctur de la musique du demandeur et les defendeurs individuets faisant l'objet des poursuites. alors le public ef les intérêts privés dans la décision relative aux questions de droits d'outeur pewvent ère saisis potur des raisons ton autres que juridiques.

\section{TABLE. OF CONTENTS}

I. Introduction ..............................616

II. IDENTITY DISCLOSURE IN UNITED STATES ONLINE MUSIC

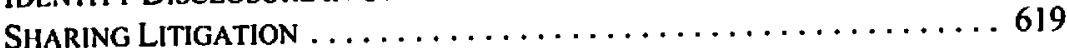

A. NON-PARTY Disclosure Under DMCA SECTION 512(H)

VS. THE U.S. FRCP

B.A.S. (Hons.) (Trent), M.I.R. (Qucen's), LL.B. (Queen's), L.L.M. (Toronto). Assistant Professor. Faculty of Law, Common Law Section. University of Ottawa. <jbailey (auottawa.ca>. This article was made possible through the generous financial contributions of Bell Canada Inc. and the Ontario Research Network for Electronic Commerce. Thanks also to Adrienne Telford, Louisa Garib, Joanna Venditti. Marina Pavlovic and Alex Cameron. Part of a prior draft of this article was presented at the Canadian Law and Society Conference in Harrison Hot Springs, British Columbia in 2005. Thanks to Colleen Hancyz for her insightful question there. 
B. Verizon's Successful Section 512(H) Challencie . . . . . . . 624

III. IDENTITY Disclosure IN CANADIAN ONLINE MUSIC SIIARING

LITIGATION $-B M G I \& I I \ldots \ldots \ldots \ldots \ldots \ldots \ldots \ldots \ldots \ldots . \ldots \ldots \ldots$

A. Canadian Proceedings against John and Jane Doe . . . . . 625

B. BMGI-DISMISSAL OF CRIA'S DISCLOSURE MOTION . . . . . 626

C. $B M G I I$ - DISMISSAL OF CRIA'S APPEAL . . . . . . . . . . 629

D. THE TEST FOR DISCLOSURE OF IDENTIFYING

INFORMATION POST-BMG I \& $I \ldots \ldots \ldots \ldots \ldots \ldots \ldots . \ldots 631$

IV. THE DMCA, BMG ANd THE QUeST FOR PROCEDURAL. JUSTICE . . . . . 632

A. The Substance of Procedure ANd the

Procedure of Substance . . . . . . . . . . . . . . . . . 632

B. SOLUM'S INTEGRATED APPROACH TO

Procedural Justice . . . . . . . . . . . . . . . . . . . 633

C. Procedural Justice in the OnLINe Music

SHARING LITIGATION .......................... 634

V. Conclusion ........................ 645

The real work of procedure is to guide conduct. It is sometimes said that the regulation of primary conduct is the work of the general and abstract norms of substantive law - clauses of the constitution, statutes, regulations, and common law rules of tort, property, and contract. But substance cannot effectively guide primary conduct without the aid of procedure....

[W]hen we regard ourselves as bound by the principles of procedural justice, we produce a very greal good - we give cilizens a principled reason to respect the outcomes of civil process.

Lawrence B. Solum'

\section{INTRODUCTION}

Since Canada signed the World Intellectual Property Organization (WIPO) Treaties, ${ }^{2}$ considerable attention has been focused on Canadian copyright reform and to what extent

Lawrence B. Solum, "Procedural Justice" (2004) 78 S. Cal. L. Rev. 181 at 320-21.

World Imellecual Propern! Organization: Copyright Treaty, 20 December 1996, S. Trealy Doc. No.105-17, 36 I.L.M. 65, online: WIPO <www.wipo.int/reaties/cn/ip/wcVindex.htm] $[$ [WCT]; WIPO Performances and Phonograms Treaty, 20 December 1996, S. Treaty Doc. No.105-17,36 I.L.M. 76, online: WIPO < www.wipo.in//reaties/en/ip/wppt/index.html> [WPPT]. The World Intellectual Property Organization (WIPO) was established formally in 1967 to promote intellectual property around the world, as well as intemational cooperation in its enforcement (Convention Establishing the World Imellectwal Property Organization, signed in Stockholm on 14 July 1967 and amended 28 Seplember 1979, online: WIPO <www,wipo.int/treaties/en/convention/Irtdocs wo029.html\#P68 3059>). In December 1996, WIPO adopted the $W C T$, in part with a view to updating international laws prolecting intellectual property in wake of the impact of digital technologies on the copyright interests of the music and cntertainment industry. Article 14 of the WCT requires signatories, such as Canada (which has not yet ratified the Treaty) and the U.S., to ensure adequate and expeditious enforcement procedures are in place against acts of in fringement covered by the Treaty. One clement of the ability to enforce copyright (or any other legal right) is, of course, the ability to identify those who have infringed the right in order to seck a legal remedy against them. As discussed below; "anonymous" Internel communication poses certain challenges in terms of identilying potential wrongdoers - renewing the importance of procedures for obtaining identifying information from third parties. 
Canada should follow the path the United States has chosen ${ }^{3}$ in domestically implementing those treaties through the Digital Millennium Copyright Act. ${ }^{4}$ One important aspect of the United States' implementation has received little attention in Canada. The $D M C A$ provides an administrative mechanism ${ }^{5}$ allowing copyright holders easier access to identifying information relating to online music sharers than that ordinarily permitted under the U.S. Federal Rules of Civil Procedure (U.S. FRCP). ${ }^{6}$ It would be easy 10 dismiss the simplification of the disclosure process as a procedural matter that should take a backseat to what might be considered the more substantive aspects of proposed legislative reform:? however, both Canadian and U.S. experience relating to disclosure of information about online file sharers suggests otherwise.

The record relating to identity disclosure in online music sharing litigation reaffirms the message conveyed in the epigraph to this article - that procedural law cannot meaningfully be separated from substantive legal outcomes or public respect for the justice system. ${ }^{8}$ The disclosure processes and outcomes in Canada's first online music sharing litigation and those in various U.S. cases involving online activity reveal the depth of the "entanglement of substance and procedure." These case studies lay bare the inexorable connection between disclosure processes, substantive rights of privacy and the ability to legally pursue wrongdoers.

Perhaps more importantly, the U.S. experience in the online music sharing context exposes the prospect that more easily obtained disclosure may be inconsistent with the public interest in adjudication of controversial aspects of substantive copyright law. In terms of furthering the goal of procedural justice, examination of the Canadian and U.S. approaches strongly supports the Canadian government's decision not to include a DMCA-style administrative disclosure mechanism in Bill C- $60^{10}$ (copyright reform legislation that died on the order

See for example, Michacl Geist. "Trade Pressures Cloud Intellectual Propeny Policy" The Toronto Star (9 May 2005), online: <www.michaelgeist.ca/resc/html_bkup/may92005.html>; Michael Geist "Government's New Copyright Plan More Balanced" The Toromto Siar (28 March 2005) C3, online: <www.thestar.com/NASApp/cs/ContentServer?pagename=thestar/LayouVArticle_Typel\&c=Article $\&$ cid $=1111963808841 \&$ call_pageid $=968350072197 \& \mathrm{col}=969048863851 \& 1 \mathrm{DPL}=-1 \mathrm{vsNDS} \% 217 \mathrm{ChA}$ X\&lacodalogin=yes >: Jack Kapica. "Copyright bill satisfies recording industry" The Globe and Mail (20) June 2005), online: <www.globelechnology.com/servle(/story/RTCiAM.20050620.gibill1620/ BNStory/Technology/>.

Pub. L. No. 105-304, 112 Stat. 2860 (1998) (codified as amended at various sections of 17 U.S.C) [DMCA].

3 lbid, s. 512(h).

- 28 U.S.C.A. (2005), online: L.gal Information Institute <www,law.cornell.cdu/rules/frep/> [U.S. FRCP].

7. For example, the Canadian government has tabled proposed copyright reform legislation relating to everything from redefinition of copyright infringement to include circumvention of technological protection measures to imposing measures supposcdly designed to facilitate distance education (Bill C. 60. An Act to amend the Copyright Act. 1st Sess.. 38th Parl.. 2005 (given first reading on 20 June 2005), onlinc: <www.parl.ge.ca/PDF/38/I/parlbus/chambus/house/bills/govemmenU(C-60_I.PI]F> [BillC.60]). Procedural law is oflen thought of simply as the rules governing litigation (c.g. rules relating to pleadings, discovery and so forth), while substantive law is used to refer to the statutes, constitutions and common law, the provisions of which dircetly guide human conduct (Solum. stipra note I at 320). Solum, ibid. at 215.

10 Bill C-60, supra note 7. Interestingly, however, the same Liberal government also tabled legislation that would have considerably reduced the procedural mechanisms in place for law enforcement agents to obtain subscriber identifying information, as well as to aecess otherwise private online communications 
paper when the election was called in the fall of 2005). At the same time, however, questions remain as to whether the current Canadian approach sufficiently protects the public interest in privacy and accuracy in substantive legal outcomes.

This article explores the adequacy and substantive repercussions of the disclosure processes employed predominantly in the Canadian and U.S. online music sharing litigation using Lawrence Solum's integrated model of procedural justice." Solum suggests that participation by interested parties and accuracy in substantive legal outcomes are the primary principles underlying procedural justice. ${ }^{12}$ The approaches to disclosure taken in the online context in both Canada and the U.S. raise questions with respect to each of these principles. The analysis here, however, suggests that the Canadian and U.S. judicially based procedures better protect and balance the substantive rights at stake than does the administrative $D M C A$ system. Even so, a more contextual and privacy-conscious version of the current judicial approach in Canada might better serve the procedural justice principles identified by Solum.

Part II of this article discusses the non-party disclosure processes employed in U.S. online litigation (focusing primarily on music sharing cases). Part III summarizes the key facts and decisions in Canada's first online music sharing case - BMG Canada v. Jolin Doe. ${ }^{13}$ Relying on the factual foundations laid in Parts II and III, Part IV introduces Solum's model of procedural justice and analyzes whether the Canadian and U.S. approaches are consistent with it. Part IV highlights the ways in which the Canadian and U.S. case studies interact with Sclum's integrated approach by: (i) reaffirming the substance/procedure connection; (ii) casting doubt upon any assumed positive correlation between fuller or more expedited rights of disclosure with accuracy of, or respect for, substantive legal outcomes (particularly in cases involving participants who are not equally financed and informed); and (iii) underscoring the importance of participation by, or representation of, interested parties even at preliminary procedural stages. The Conclusion suggests that the absence of a $D M C A$-style administrative disclosure process in Bill C-60 was well-founded in procedural justice terms. If anything, Canada should consider strengthening protections for online privacy in the civil non-party disclosure process.

(Bill C-74, Modernization of Investigative Teclmiques Act, Ist Sess., 38th Parl., 2005 (given first reading 15 November 2005), online: <www,parl,ca/38/1/parlbus/chambus/house/bills/governinent/C-74/C. 74_I/C-74_cover-E.html>).

Solum, supra note 1.

lid.

BMG Canada v. John Doe, [2004] 3 F.C. 241, 2004 FC 488 (T.D.) [BMG ], afrd (2005), 334 N.R. 268, 2005 FCA 193 [BMG II]. 


\section{IDENTITY DISClosuRE IN UNITEd STATES ONLINE. MUSIC SHARING LITIGATION}

Between June and September of 2003 the Recording Industry Association of America (RIAA) filed the first $261^{14}$ of what would ultimately become more than $11,000^{15}$ actions against individuals alleged to have violated the copyright of RIAA members through online music sharing. In order to initiate individual actions against named defendants, RIAA first had to overcome unique features of online music sharing (and indeed Internet communication more generally) - anonymity and pseudonymity.

Many people participate in online communications using pseudonyms ${ }^{16}$ that do not reveal their "real space" identities. As a result, one of the first steps in initiating an action in relation to online communication is to obtain disclosure of the identity of the online participant alleged to have engaged in wrongdoing. Plaintiffs such as RIAA are able to take publicly available information relating to the Internet Protocol (IP) address ${ }^{17}$ from which an allegedly wrongful communication originated and identify the Internet Service Provider(ISP) to whom that IP address was assigned at the time of the relevant communication. ${ }^{18}$ Plaintiffs then turn to ISPs for disclosure of information identifying the subscriber associated with the IP address at the time of the alleged wrongdoing. ${ }^{19}$ Although ISPs may be able to identify the subscriber assigned a particular IP address at a particular point in time, it is noteworthy that the subscriber whose confidential information is disclosed may not be the person engaged in an allegedly wrongful activity. Others in the subscriber's houschold or place of business may well have been using the Internet connection at that particular point in time.

Lisa Rein, "Commentary: What's Real and Make-Believe with the RIAA Subpoenas?" (11 September 2003), online: O'Reilly Openp2p.com <www.openp2p.com/pub/a/p2p/2003/09/11/riaa_supoenas. $\mathrm{html>;}$ Roy Mark "House Action on RIAA Subpoenas Unlikcly" (22 September 2003), online: Dc.Internet.com <http://dc.intemet.com/news/article.php/3080841>.

Steve Knopper, "RIAA Will Keep On Suing" (9 Junc 2005), online: The Rolling Stone $<w w w$.rollingstone.com/news/story/_id/7380412>. Other reported ligures suggest that RIAA filed some 13,300 federal lawsuits between September 2003 and August 2005 (Timothy O'Connor. "Taking on record companies" (14 August 2005). online: The Journal News <www.thejoumalnews.com' apps/phes.dI l/anicle?AID=/20050814/NEWS02/508140316/1020/NEWSO4>).

is A pseudonym may reveal something about the true identity of an online communicator (e.g. IlelensMom) or it may not (e.g. getekboy (akazaa.ca). Interestingly, the Internet both presents challenges to copyright enforcement, as well as facilitating it. Unlike much ofline copying of copyrighted works, online copying is often done in relatively public online fora - so although it may be a challenge to identify exactly who the person is behind pseudonymous or anonymous Intemel communication, the industry perhaps has a better record than ever of the sharing of copyrighted works.

An IP address is a unique "identifier for a computer or device" on the Internet, consisting of "a 32-bit numeric addness written as four numbers scparated by periods" (c. \&. 24.84.179.98) (Webopedia. online: <http://webopedia.com/TERM/lP_address.html>).

17 ISPs, such as Sympatico, Rogers and Telus, are assigned blocks of IP addresses, which they in tum mete out to their subseribers as he or she "signs on" to the Inteme. Although IP' addresses are like phone numbers in the sense of being unique (no two devices can be signed onto the Intemet using the same IP address at the same time), they can be unlike phone numbers since they are typically dynamically assigned (and so are not usually consistently attached to a particular subscriber or device) (Nationmaster.com, online: <www.nationmasler.com/encyclopedia/lP-uddress $>$ ).

19 While ISPs are repositories of information about their subscribers, in Canada they have not typically been named as parties to litigation against their subscribers. 
RIAA initiated its first 261 suits against named defendants after it obtained subscriber information from various ISPs in the U.S., following some $1,600^{20}$ subpoena applications made pursuant to the expedited administrative disclosure process under $\mathrm{s} .512(\mathrm{~h})$ of the $D M C A$. By October 2003, a database maintained by the Electronic Frontier Foundation $(E F F)^{21}$ included 1,568 subpoenas issued under s. 512(h) against alleged infringers. ${ }^{22}$

By June 2005, RIAA had sued some 11,456 people, 2,484 of whom are reported to have paid RIAA an average of $\$ 3,600$ to settle their cases out of court in the face of claimed damages of up to $\$ 150,000$ per song alleged to have been illegally shared. ${ }^{23}$ There is no record of any of these cases proceeding to trial. ${ }^{24}$ Out-of-court settlements and the accompanying lack of public adjudications appear commonplace despite the fact that many of those sued on the basis of subscriber information obtained from ISPs have never engaged in filesharing of any kind. ${ }^{25}$ RIAA's President Cary Sherman characterizes the strategy as a "tough-love form of education" that "really works" in terms of "public perception."26 Rhetoric notwithstanding, statistics are conflicting as to whether the litigation strategy has

Rein, stupra note 14.

Subpocna Database Query Tool, online: Electrunic Frontier Foundation <www.eft.org/IP/P2P/riaa subpocnas/> (this database is now disubled). See also EFF, "Unsafe Harbors: Abusive DMCA Subpocnas and Takedown Demands," online: Electronic Fronticr Foundation <www.efl.org/IP/P2P/ 20030926_unsafe_harbors.php>.

EFF's Subpoena Database Query Tool, ibid., allows individuals to enter their names to find out whether a subpoena had been issued to an ISP ordering disclosure of the identities of customers suspected of copyright infringement. The entries are taken from the PACER database, <http://pacer.psc. uscourts.gov/pacerdesc.html> a pay-per-use public access service used to obtain case and docket information from U.S. Federal Appellate, District and Banknuptcy courts. Much of the data relating to lawsuits, subpoenas and settlements are approximate. There is no obligation under the DMCA to report on the subpoenas issued. There appear to be no freely available public sources of information on any of these issues, although organizations such as EFF and the Electronic Privacy Information Center (EPIC) (through a recent freedom ol information request) have struggled to obtnin and publish it. Knopper, supra note 15. $\mathrm{O}^{\prime} \mathrm{Connor,}$, supra note 15, reports the average seltlement at US\$4,000-\$5,000. Metro-Goldwyn-Mayer Studios v. Grokster I.td., 125 S. CI. 2764 (2005) (Brief of Amicus Curiae Sharman Networks Limited in Support of Respendents), online: <www.sims.berkeley.edu/ academics/courses/is296a-2/s05/grokster/20050301_sharman.pd $B ; O^{\prime}$ Connor, ibid. However, at least ont case was decided against a filesharer on a motion for summary judgment (BMG Music v. Gonzalez, 430 F.3d 888 (7th Cir. 2005).

Frequently, the Intemet service subscriber is not the person engaged in filesharing, although others within the same household were (Knopper, supra nole 15); Electronic Frontier Foundation, Media Release, "Electronic Frontier Foundation Defends Alleged Filesharer: Another Error in Record Companies" Legal Crusade" (14 October 2003), online: Electronic Frontier Foundation <www.elT.org/IP/P2P/20031014_eff_pr.php>; Fred von Lohmann, "Perspective: RIAA's college lawsuits a wrong answer" CNET News (14 September 2003), online: CNET News.com <http://news.com.com/2010-1069-5075853.html> ("in the RIAA's war on lile sharing, everyone is guilty until proven innocent"): Electronic Frontier Foundation, Media Release, "Recording Industry Withdraws Music Sharing Lawsuit: Lack of Due Process Leads to Mistaken Identity" (24 September 2003), online: Electronic Frontier Foundution <www.efr.org/IP/P2P/20030924_eff_pr.php $>$ [EFF 24 September 2003]. 
actually deterred online music sharing, ${ }^{27}$ as well as to how much of the decline in music sales in recent years is actually attributable to online infringement. ${ }^{28}$

As discussed below, it would appear that most of the cases initiated after the end of $2003^{39}$ did not rely upon information obtained through the s. 512(h) procedure, given RIAA's resounding December 2003 appellate loss in court challenges launched by the ISP Verizon. ${ }^{30}$

\section{A. NON-PARTY Disclosure UNder DMCA SECTION $512(H)$ VS. THE U.S. FRCP}

The DMCA was enacted in 1998 to extend copyright to emerging digital technologies and in accordance with the U.S. government's interpretation of its obligations under the WIPO Treaties. ${ }^{31}$ Section $512(\mathrm{~h})$ of the $D M C A$ made available a new subpoena power to expedite ISP disclosure of subscriber-identifying information to copyright holders. ${ }^{32}$

Section 512 (h) allows copyright holders (or their representatives) to apply to any clerk of the U.S. District Court for a subpoena ordering an ISP to disclose identifying information about an alleged infringer. In order to obtain the subpoena, copyright holders (or their representatives) must personally file with the clerk: ${ }^{33}$

Ihid. (BigChampagnc, a company that tracks filcsharing trends, suggested that trading in copyright songs increased 100 pereent from Seplember 2003 (just affer initiation of the first law suits) to April 2005); Lee Rainic et al., "Pew Intemet Project and Comscore Media Metrix Data Memo Re: The stale of music downloading and file-sharing online" (April 2004), onlinc: Pew Internet \& American Life Project <www.pewintemet.org/pdfs/PIP_Filesharing_A pril_04.pdi> [Pew Study 1]. A more recent study by the same authors also suggests there has been an overall decline in music downloading, although it is not clear whether they connect it to threat of litigation: Mary Madden \& Lee Rainie, "Music and Video Downloading Moves Beyond P2P" (23 March 2005), online: Pew Intemet \& American Life Project <www.pewinternet.org/PPF/r/153/report_display.asp $>$ [Pew Study 2] ("The percentage of intemet users who say they download music files has increased from $18 \%$ (measured in a February 2004 survey) to $22 \%$ in our latest survey from January 2005 . Still, this number continues to rest well-below the peak level $(32 \%)$ that we registered in Octoher $2002 ")$.

Daniel J. Gervais. "The Price of Social Norms: Towards a Liability Regime for File-sharing" (2004) 12 J. Intell. Prop. L. 39 at 46: Michatl Geist. "Tarifss the real threat to music downloading" The Toronto Star (18 April 2005) C 12.

For example, RIAA's website indicates that in January and February 2004, it initiated lawsuits against 1063 individual filesharers using the John Doe litigation process (RIAA, News Release, "53I More File Sharers Targeted in Latest RIAA Legal Efforts" (17 February 2004), online: Recording Industry Association of America <www.rian.com/news/newsletter/021704.asp>). Re Verizon Internet Services, 240 F. Supp. 2d 24 (D.D.C. 2003) [Verizon I]; Re Verizon Internet Services, 257 F.Supp. 2d 244 (D.D.C. 2003) [Verizon II]; Recording Indusiry Association of America. Inc. v. Verizon interner Services, Inc.. 359 U.S. App. D.C. 85 (D.C. Cir. CA 2003) [Verizon III]. Amy P. Bunk. "Validity, Construction, and Application of Digital Millennium Copyright Act" (1998) 179 A.L.R. Fed. 319.

12 Trevor A. Dutcher, "A Discussion of the Mechanics of the DMCA Safe Harbors and Subpoena Power, as Applied in RIAA v. Verizon Intermet Services" (2005) 21 Santa Clara Computer \& High Tech. L.J. 493 at 498.

33 Bunk, supra note 31. See also RIAA, News Release, "Backgrounder News Memo Debunking Myths Raised By Verizon In Court Dispute," online: RIAA <www.riaa.com/news/filings/verizon_ backgrounder.asp>. 
(i) a sworn written statement "to the effect that the purpose for which the subpoena is sought is to obtain the identity of an alleged infringer and that such information will only be used for the purpose of protecting rights under" the $D M C A ; ;^{34}$

(ii) a proposed subpoena; ${ }^{35}$ and

(iii) a written notification of claimed infringement. ${ }^{36}$

The clerk must issue the subpoena expeditiously if the proper documentation is filed. ${ }^{37}$ The subpoena itself is to
authorize and order the service provider receiving the notification and the subpoena to expeditiously disclose to the copyright owner or person authorized by the copyright owner information sufficient to identify the alleged infringer of the material described in the notification to the extent such information is available to the service provider. ${ }^{38}$

On receiving the subpoena, the ISP is to expeditiously disclose the information to the complaining party. ${ }^{39}$

Section 512 (h) stands in contrast with the U.S. $F R C P^{10}$ as it relates to discovery of nonparties. $F R C P$ r. 45 enables parties to have subpocnas issued only where an action has already been commenced. Further, unlike s. 512(h), r. 45(3) expressly requires a court, on motion, to quash or modify a subpoena where it, among other things, "requires disclosure of privileged or other protected matter and no exception or waiver applies." empowers a reviewing court to quash or modify a subpoena where, among other things, the subpoena "requires disclosure of ... confidential ... commercial information"42 or to order production or appearance on specified conditions if the party seeking disclosure shows "a substantial need for the testimony or material that cannot be otherwise met without undue hardship." ${ }^{43}$ Rule 45 also seeks to ensure that the non-party will be reasonably compensated for any substantial related expenses. ${ }^{44}$

Judicial oversight in the context of $\mathrm{r}$. 45 disclosure from non-parties has in some cases led to the implementation of relatively strict standards of proof where the information sought

DMCA, supra note 4, s. $512(\mathrm{~h})(2)(\mathrm{C})$.

Ibid., s. 512(h)(2)(B).

lbid., s. $512(\mathrm{~h})(2)(\mathrm{A})$. Section $512(\mathrm{c})(3)(\mathrm{A})$ states that the written notice is to include "substantially" all of the following information: (i) a signature of the rightsholder or agent; (ii) identification of allegedly infringing material; (iii) sufficient information to allow the ISP to contact the complainant; (iv) a good faith statement that the use of the material is not authorized by the rightsholder; and (v) a statement that the information provided is accurate and, under penalty of perjury, that the complainant is authorized to aet for the rightsholder.

Ibid., s. S12(h)(4).

Ibid., s. 512(h)(3).

Ibid., s. 5|2(h)(5).

Supra note 6.

Ibid., r. 45(c)(3)(A)(iii).

lbid., r. 45(c)(3)(B)(i).

Ibid., r. 45(c)(3)(B)(iii).

lbid. 
involved identification of an alleged wrongdoer. The standards imposed by various courts in the U.S. reflect a balancing of the First Amendment protected right to anonymity with a litigant's interest in disclosure. ${ }^{\text {t5 }}$

In an effort to balance the interest of a trademark holder in seeking legal redress with an online user's constitutionally protected right to speak anonymously, the California court in SeesCand $y^{\text {th }}$ required the trademark holder to:

(i) "identify the missing party with sufficient specificity such that the Court can determine that defendant is a real person or entity who could be sued in federal court":47

(ii) "identify all previous steps taken to locate the elusive defendant";

(iii) "establish to the Court's satisfaction that plaintiff's suit against defendant could withstand a motion to dismiss.... [The] plaintiff must make some showing that an act giving rise to civil liability actually occurred and that the discovery is aimed at revealing specific identifying features of the person or entity who committed that act"; and

(iv) "file a request for discovery with the Court, along with a statement of reasons justifying the specific discovery requested as well as identification of a limited number of persons or entities on whom discovery process might be served and for which there is a reasonable likelihood that the discovery process will lead to identifying information about defendant that would make service of process possible." 48

The Court noted that these strict standards of proof were necessary to "prevent abuse of this extraordinary application of the discovery process." similar approaches. Some have imposed balancing tests that require parties seeking disclosure of identifying information about alleged defamers and intellectual property

Jeffrey M. Levinsohn, "Protecting Copyright at the Expense of Internet Anonymity: The Constitutionality of Foreed Identily Disclosure Under Section $512(\mathrm{~h})$ of the Digital Millennium Copyright Act" (2004) 23 Temp. Envil. L. \& Tech. J. 243 at 259-60. The U.S. District Coun in Connecticut concluded, however, that subscriber informution was not protected by the Fourth Amendment right to due process where, among other things, the subscriber's agreement specifics that his or her ISP may divulge that information under certain circumstances (Freedman v: America Online, [2005] WL. 1899381 (D.Conn.) (WL) [Freedman]).

1) Ibid. at 578. The jurisdiction in which the process is initialed can be extremely important in terms of substantive results. If plaintiffs are not required to demonstrate at least a preliminary case for the issuing court to exercise jurisdiction. plaintiffs may gain an important tactical advantage against less-resourced defendants who reside in other jurisdictions. In the online music sharing context, many individuals have been sued in jurisdictions where their ISPs are hesadquartered, even though the individual subscribers reside far from that location (EFF. "A Motion to Ask the Court to Require the Record Companies to Sue You in Your Local Courts," online: Electronic Frontier Foundation <www.eff.org/IP/P2P/riaa-v-the people.php?f=local_motion.html>). 
infringers to demonstrate to the Court prima facie cases ${ }^{50}$ against the alleged wrongdoers, while others require simply proof of a good faith belief in such a case. ${ }^{51}$

The expedited administrative process under s. $512(\mathrm{~h})$ has been criticized on numerous fronts $^{52}$ - in particular for the apparently low threshold pursuant to which subpoenas are required to issue, the absence of notice to alleged infringers (and their concomitant inability to ensure that their anonymity and expressive interests are adequately taken into account in determining whether the subpoena should be issued) and the absence of a specific provision for appealing subpoena issuance. ${ }^{53}$ These and other criticisms have formed the basis for court challenges to s. $512(\mathrm{~h})$. One of these challenges appears to have been instrumental in RIAA's decision to switch from using s. 512(h) for advance disclosure to using the ordinary rulesbased provisions after initiating John and Jane Doe litigation.

\section{B. Verizon's Successful SECTION 512(H) Challenge}

Verizon's success on appeal in two s. 512(h) challenges appears to have triggered a change in RIAA's non-party disclosure strategy. Verizon twice refused to comply with subpoenas RIAA had obtained pursuant to s. 512(h) and advanced both a statutory interpretation and a constitutional basis for its refusals to comply. With respect to the statute, Verizon argued that the $D M C A$ provision only applied to disclosure of information stored on an ISP's server, rather than on a subscriber's computer. ${ }^{54}$ On the constitutional side, Verizon argued that the "good faith" threshold for obtaining a s. 512(h) subpoena failed to provide sufficient procedural protection for subscribers' First Amendment rights to anonymity and free speech."s

Verizon was unsuccessful at first instance on both of its challenges, ${ }^{56}$ but succeeded in a combined appeal before the D.C. Circuit Court of Appeals, which released its decision in December 2003. ${ }^{57}$ The D.C. Court vacated the subpoenas on the basis of Verizon's statutory interpretation point, without deciding the constitutional question. Since the United States

Dendrile In' $\%$ ฯ. Doe. No. 3, 775 A.2d 756 at 767-68 (N.J. Super. Cl. App. Div. 2001): Sony Music Entertainment v. Does 1-40, 326 F.Supp. $2 \mathrm{~d} 556$ at 565 (S.D.N.Y. 2004); Rocker Managemen LLC v. John Doc, 2003 U.S. Dist. LEXIS 16277 at 7.8 (N.D. Cal. 2003) (finding the plaintiff had nol proven a statement actionable for libel had been made); Elektra Entertainmen Group v. Doe 2004 U.S. Dist. LEXIS 23560 at 10 (S.D. N.Y. 2004).

In re Subpoena Duces Tecum to America Online, $52 \mathrm{Va}$. Cir. 26 at 8 (Va. Cir. Cl. 2000); Doe v. 2TheMarr.Com, 140 F. Supp. 2d 1088 (W.D. Wash. 2001 ); Virologic v. Doe, 32 Mcdia L. Rep. 2219 (Cal. App. 1 Dist. 2004) (applying the "good cause" (est set out in the anti-SLAPP statute at issuc). See e.g. Levinsohn, supra note 45 at 264-65; Ed Felten, "Bring on the Subpoena-Bots!" (3 August 2003), online: Freedom to Tinker Blog <www.freedom-to-tinker.com/archives/000421.html>; Rein, supra note 14; Mark supra note 14. While it was later concluded judicial review of the subpoena was available pursuant to $r .45$, it is not obvious how anonymity would be protected in such circumstances (Verizon $I l$, supra note 30 at 263). For Verizon's statutory interpretation argument sec Reply Brief for Appellant, for Verizon III, supra note 30. at 8-17), online: Electronic Frontier Foundation <www.eff.org/legal/cases/RiAA_v_Verizon/ 20030717_verizon_reply_brief.pdis.

st Verizon's full constitutional argument can be found in the Brief of Alliance for Public Technology et al. for Verizon III, ibid., online: Electronic Frontier Foundation <www.ef.org/legal/cases/RIAA_v.
Verizon/20030516_eff_amicus.pdP.

S. Verizon $J$ and Verizon $\bar{I}$, supra note 30.

3. Verizon III, supra note 30. 
Supreme Court denied RIAA's application for cerriorar $i^{\text {sx }}$ the D.C. appellate decision on the interpretation question stands, ${ }^{59}$ although the constitutionality of $\mathrm{s} .512(\mathrm{~h})$ remains unclear. ${ }^{60}$

\section{IDENTITY Disclosure IN CANAdiaN ONLINE MUSic ShaRing Litigation - BMG I \& II}

\section{A. Canadian Proceedings against Jolin and Jane DoE}

On 10 February 2004 BMG Canada (BMG), together with 16 other companies that own copyright in various sound recordings (hereinafter collectively referred to as $\mathrm{CRIA}^{61}$ ), filed with the Federal Court of Canada a statement of claim against "John Doe, Jane Doe and All Those Persons Who Are Infringing The Plaintiffs' Copyright In Sound Recordings," allegedly through illegal online filesharing. ${ }^{62}$ The CRIA lawsuit was in many respects a copycat version of RIAA lawsuits in terms of its stated objectives relating to public education and deterrence. ${ }^{63}$ However, in the absence of an expedited administrative process like the one under s. 512(h) of the DMCA, CRIA elected to proceed by first issuing a statement of claim against Jane and John Doe and then immediately moving for discovery from the relevant ISPs.

CRIA filed its motion pursuant to the Federal Courl Rules ${ }^{\text {it }}$ for discovery of five ISPs who had allegedly provided service to 29 individual filesharers claimed to have infringed the plaintiffs' copyright. ${ }^{65}$ The notice of motion stated that an investigation had been conducted on behalf of the plaintiffs, revealing that persons identified only through pseudonyms had used certain IP addresses assigned to those ISPs to engage in filesharing infringing the

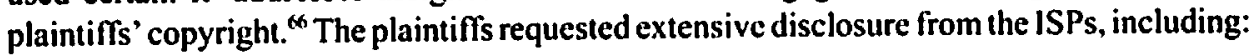

Recording Industry Association of America v. Verizon Internet Services, 125 S.Ct. 309 (2004).

At least one other court reached a similar conclusion on the statulory interpretation point, some also expressing concern as to s. 512 (h)'s constitutionality (Recording Indusrry Association of America v. Charter Communications, Subpoena Enforcement Momer 393 F:3d 771 (81h Cir. CA 2005)).

Constitutional arguments were raised in Pacific Bell mernet Services v. Recording Indusiry Association of America, [2003] WL 22862662 (N.D. Cal.) (WL), but following a decision rejating to jurisdiction. the matter does not appear to have been adjudicated upon. Constitutional concerns relating to abuse of s. $512(f)$ of the DMCA were also raised, but dismissed (primarily relating to a question of standing) in Fatwallet, Inc. v. Best Buy Enterprises Services, [2004] WI. 793548 (N.D. Ill.). The Freedman decision, however, suggests that, in terms of Fourth Amendment protections, divulging subscriber information may not raise due process concerns under the U.S. Constitution (Freedman, supra note 45).

The 17 named plaintiff companies are members of the Canadian Recording Industry Association (CRIA), which appears to be playing a pivotal role in directing the litigation. See details on CRIA's website, online: <www.cria.ca/news.php>.

Statement of Claim for B.MG I, supro note 13, online: Canadian Internet Policy and Public Interest Clinic <www.cippic.ca/en/projects-cases/file-sharing-lawsuits/CRIAStalementofClaim.pdrs.

CRIA. News Release, "The Canadian recording industry condemns government inaction on copyright: Canadian recording industry takes next step in lawsuits against music pirates" (13 February 2004). online: CRIA <www.cria.ca/news/130204_n.php>. Federal Courı Rules, 1998, S.O.R./98-106 [FCR]. sharing-lawsuits/NoticeOfMotion.pd $\$$ [Notice of Motion]. Notice of Motion, ibid. at paras. 2(c) and (d). 
(a) the last known name; home, mailing and business addresses; telephone numbers; facsimile numbers and c-mail addresses in the business records of the ISP associated with the IP Addresses and dates and times listed in [a schedule attached to the proposed order]; and

(b)

... a copy of the ISP's records used to identify the information disclosed pursuant to subparagraph (a), which copies may be redacted by the ISP prior to production to remove irrelevant information. ${ }^{67}$

\section{B. BMG I-Dismissal of CRIA's DisClosUre Motion}

In its notice of motion CRIA claimed that without disclosure of subscriber-identifying information relating to the listed IP addresses, its members would be prevented from enforcing their copyrights. CRIA also indicated its plan to use the information obtained to initiate separate applications or actions against each of the individuals identified. ${ }^{68}$

In sharp contrast with what appears to have been standard procedure for Canadian ISPs prior to the BMG litigation, all five ISPs served with CRIA's notice of motion actually appeared when the motion was argued, four of them opposing it. ${ }^{69}$ Two public interest groups granted intervener status were also present at the hearing and opposed the motion. ${ }^{70}$ The subscribers whose privacy was at stake did not participate in the motion.

The Federal Court (Trial Division) (FCTD) dismissed the motion, issuing a set of reasons that "propelled Canada into the international spotlight because of the Court's statements regarding the legality of sharing music files on P2P networks." ${ }^{71}$ Commentary on the substantive law aspects of the case ${ }^{72}$ has overshadowed, and perhaps obfuscated, the equally important and intimately connected procedural aspects of the case.

In dismissing CRIA's motion, von Finckenstein J. found that CRIA was not entitled to rely on $\mathrm{r}$. 233 of the $F C R$, since the information sought would require creation of new documents, while the $r .233$ documentary discovery provision relates only to production of documents already in existence. ${ }^{73}$ However, he concluded there were two other procedural mechanisms through which the plaintiffs could seek disclosure: (i) an equitable bill of

Order in B.MG I.stupranole 13, online: CIPPIC < www.cippic.ca/en/projects-cases/file-sharing-lawsuits/

Schedule-A-Order.pdis al paras. I(a) and (b).

as Notice of Motion, supra nole 65 at paras. 2(g) and (j).

th would appear quite commonplace for plaintiffs to seek and obtain orders compelling production of subscriber-identifying information from ISPs in motions to which no one ever appears to respond. See Invin Toy Lud. v. Doe (2000), 12 C.P.C. (5th) 103 (Ont. S.C.J.) [Inwin Toy]; Ontario First Nations Limited Partnership v. John Doe (3 June 2002) (Ont. Sup. Ct.) [Omario First Nations]; Canadian Blood Services/Sociélé Camadienne du. Sang v. John Doe (17 June 2002)(Ont. Sup. Ct.) [CBC]; Wa'el Cheliab v. John Doe (3 October 2003) (Ont. Sup. Ct.) [Wa'el Chehab].

71) The inteveners were the Canadian Internet Policy and Public Interest Clinic and the Electronic Frontier Canada. See lan Kerr \& Alex Cameron, "NYMITY, P2P \& ISPs: Lessons from BMG Canada lic. v. Joln Doe" in K.J. Strandburg \& D.S. Raicu, eds., Privacy and Techonologies of demtity: A CrossDisciplinary Conversation (New York: Springer, 2005)[ forthcoming 2005] at 6, online: On the indentity Trail Blog < http://idtrail.org/contenU blogeategory/20/7/> (citing to online pages).

"Ihid. at 5 .

" United States Trade Representative, "2005 Special 301 Report" (29 April 2005), online: Oflice of the United States Trade Representative <www.ustr.gov/assets/Document_Library/Reports_Publications/ 2005/2005_Special_301/asset_upload_file195_7636.pdf $>$ at 37.

BMG I, supra note 13 at para 15 . 
discovery at common law (which can be brought without having to first initiate a proceeding); and (ii) r. $238^{74}$ of the FCR, which empowers the FCTD to order discovery of a non-party after a proceeding has been initiated. ${ }^{35}$ He reasoned that the test for establishing a right to an equitable bill of discovery should apply equally to obtaining non-party discovery under r. 238 and articulated the criteria as follows:

(a) the applicant must establish a prima facie cuse against the unknown alleged wrongdoer;

(b) the person from whom discovery is sought must be in some way involved in the matter under dispute. he must be more than an innocent bystander;

(c) The person from whom discovery is sought must be the only practical source of information available to the applicants;

(d) the person from whom discovery is sought must be reasonably compensated for his expenses arising out of compliance with the discovery order in addition to his legal costs; [and]

(c) the public interests in favour of disclosure must outweigh the legitimate privacy concems. ${ }^{76}$

The FCTD found that CRIA had failed to satisfy the first, third and fifth criteria. The Court's findings in relation to privacy and the public interest were intimately connected with its conclusions relating to the first and third. With respect to the first criterion, the Court concluded that CRIA had failed to establish a prima facie case for three reasons:

(i) the affidavit from CRIA's key witness ${ }^{77}$ was deficient in that it consisted largely of hearsay without any statements as to the source of the information or the basis for the affiant's belief in its truth; ${ }^{78}$

(ii) CRIA filed no evidence as to how the pseudonyms and the IP addresses in respect of which CRIA sought subscriber information were connected; ${ }^{79}$ and

(1) A party to an action may bring a motion for leave to examine for discovery any person not a party to the action ... who might have information on an issue in the action

(3) The Court may ... grant leave to examine a person ... if it is satisfied that

(a) the person may have information on an issue in the action;

(b) the party has been unable to obtain the information informally from the person or from another source by any other reasonable means:

(c) it would be unfair not to allow the party an opportunity to question the person before trial; and

(d) the questioning will not cause undue delay, ineonvenience or expense to the person or to the other parties. by CRIA to investigate filesharing of songs in which the plaintiffs held copyright (ibid. at para. 17). 
(iii) CRIA filed no evidence that the plaintiffs' copyright had been infringed in that one does not infringe copyright by downloading a song for personal use, one does not authorize infringement simply by placing personal copies of music on a shared directory accessible to others through a P2P service, and there was no evidence that the alleged infringers knew they were infringing copyright (which would be necessary to ground a secondary infringement claim). ${ }^{g 0}$

With respect to the third criterion - whether the ISPS were the only practical source of the information sought - von Finckenstein J. noted the possibility that identifying information relating to the alleged infringers might be obtained from those operating the websites from which the filesharing software was downloaded. CRIA's failure to address that in its evidence left open the possibility that there were other practical sources of the information available. ${ }^{81}$

With respect to the fifth criterion, the FCTD noted that "the protection of privacy is of utmost importance to Canadian society, ${ }^{182}$ as demonstrated in various judicial decisions and in Parliament's enactment of the Personal Information Protection and Electronic Documents $A C t^{83}$ The Court concluded that, given the age of the data on which CRIA relied, its unreliability and "the serious possibility of an innocent account holder being identified," the "privacy concerns outweigh the public interest concerns in favour of disclosure." evidence filed by some of the ISPs indicated that the older the information relating to IP addresses, the less likely it was that they could produce the requested identifying information and that, even if they could produce the information requested, the more likely it was to be unreliable. ${ }^{85}$ The two- to four-month gap between CRIA's collection of this information and the filing of the motion led the Court to conclude that the risk of invading the privacy of "innocent" account holders was too great.

The FCTD noted, however, that had CRIA satisfied all of the criteria, the privacy interests of the potential defendants could be adequately safeguarded with a restrictive disclosure order. In particular, the Court noted:

[B]cfore making the order, the Court evidently must be satislied that the information about to be disclosed is reliable and should restrict disclosure to the minimum required for the plaintiffs to identily an alleged defendant. Any order made should also, having in mind the privacy interests of the defendants, be accompanied by restrictions and confidentiality orders as the Court sees appropriale.

CRIA appealed the FCTD's decision. 


\section{BMG II-DismisSAL OF CRIA'S APPEAL}

On 19 May 2005 the Federal Court of Appeal (FCA) dismissed CRIA's appeal. The opening paragraphs of the Court's reasons encapsulated the case as follows:

This case illustrates the tension existing between the privacy rights of those who use the Internet and those whose rights may be infringed or abused by anonymous Internet uscrs....

Citizens legitimately worry about encroachment upon their privacy rights. The potential for unwarranted intrusion into individual personal lives is now unparalleled. In an era where people perform many tasks over the Internet, it is possible to leam where one works, resides or shops, his or her linancial information. the publications one reads and subscribes to and even specific newspaper articles he or she has browsed. This intrusion not only puts individuals at great personal risk but also subjects their views and beliefs to untenable scrutiny. ${ }^{87}$

The FCA upheld the FCTD's conclusions that:

(i) Rule 233 of the FCR did not empower a court to order production of documents from non-parties where the documents were not previously in existence; ${ }^{\mathrm{XK}}$

(ii) CRIA's affidavit material was deficient in that "[m]uch of the crucial evidence" was hearsay and no grounds were stated for belief in or reliance on that evidence. The FCA noted in particular that "the evidence purporting to connect the pseudonyms with the IP addresses was hearsay thus creating the risk that innocent persons might have their privacy invaded and also be named as defendants where it is not warranted":;" and

(iii) CRIA's motion could be brought under r. 238 or by way of application for an equitable bill of discovery, and that the test for obtaining disclosure would be the same in either case. ${ }^{90}$

The FCA noted that the deficiency in CRIA's affidavit evidence was a sufficient basis on its own to warrant dismissing the appeal.91 Nonetheless, the FCA went on to draw these specific conclusions relating respectively to the first, third and fifth criteria for obtaining nonparty discovery:

(i) applicants need not demonstrate they have a prima facie case. Rather they are only required to show they have a bona fide claim against those in respect of whom they seek identifying information; ${ }^{92}$ 
(ii) applicants must provide clear evidence the information cannot be obtained from another source, which in the case at bar would require proof that the operators of the named websites could not provide the information; ${ }^{93}$ and

(iii) "the public interest in favour of disclosure must outweigh the legitimate privacy concerns of the person sought to be identified if a disclosure order is made."

After discussing the importance of balancing privacy rights and the public interest in favour of disclosure evident in PIPEDA ${ }^{95}$ as well as in the case law relating to equitable bills of discovery, ${ }^{\text {to }}$ the FCA affirmed the public interest in protecting intellectual property as a means of ensuring the "promulgation of ideas." "The Court concluded that privacy concerns had to be taken into account, but should also "yield to public concerns for the protection of intellectual property rights in situations where infringement threatens to erode those rights" so long as plaintiffs can show a bona fide claim that unknown persons are infringing their copyright. The FCA concluded that courts should exercise caution in ordering disclosure to insure that "privacy rights arc invaded in the most minimal way." It endorsed the following precautions:

(i) a court may well be justified in refusing to make a disclosure order where plaintiffs:

a. fail to take the greatest care to avoid delay between investigating and requesting information; ${ }^{100}$ and/or

b. "extract private information unrelated to copyright infringement, in their investigation," thereby unjustifiably intruding on users' rights and, leaving ISPs open to prosecution under PIPEDA; $;^{101}$ and

(ii) if a court grants disclosure, the order should provide "specific directions" as to the "type of information disclosed and the manner in which it can be used," and where evidence of infringement exists, a court may order that the defendant be identified only by initials and may issue a confidentiality order. ${ }^{102}$

Finally, the FCA concluded that the FCTD's findings with respect to copyright infringement should not have been made on a preliminary motion. After discussing possible alternative views to those expressed by the FCTD with respect to the application of copyright law to filesharing, the Court stated:

lbid. at para. 35.

Ibid. at para. 36.

PIPEDA, stupra note 83.

$B M G$ II, supra note 13 at para. 39.

thid. at para. 40.

Ibid. at para. 41.

Ibid. al para. 42.

Here, the FCA reflected on the fact that delays between investigation and bringing a motion increase the chances that the IP address information will be inaccurate, raising the prospect that "'the privacy rights of innocent persons would be infringed and legal proceedings against such persons would be without justification" (ibid. at para. 43).

lbid. at para. 44.

lbid. at para. 45. 
The danger of making such findings at the early stages of this case can be seen. I make no such findings here and wish to make it clcar that if this case proceeds further, it should be done on the basis that no findings to date on the issue of infringement have been made. ${ }^{103}$

The Court noted that its order was without prejudice to CRIA's right to commence a further application for disclosure, taking its reasons into account and made no order as to costs "[h]aving regard to what must be considered as divided success on this appeal."104

\section{THE TEST FOR DISCLOSURE OF IDENTIFYING INFORMATION POST-BMGI\& $I I$}

In light of the conclusions in $B M G I \& I I$, plaintiffs pursuing matters in the Federal Court may seek disclosure of the identities of alleged online wrongdoers from ISPs either pursuant to r. 238 or to the common law relating to equitable bills of discovery. ${ }^{105}$ In either case, the criteria for obtaining disclosure would appear to include the following:

(i) the applicant must demonstrate a bona fide claim against the alleged wrongdoer (which apparently does not require evidence supporting each element of proof necessary to support an infringement claim);

(ii) the person from whom discovery is sought must be in some way involved in the matter under dispute (she or he must be more than an innocent bystander);

(iii) the person from whom discovery is sought must be the only practical source of information available to the applicants (which, in the context of filesharing, requires evidence that the information cannot be obtained from the website operators making the filesharing software available);

(iv) the person from whom discovery is sought must be reasonably compensated for his or her expenses arising out of compliance with the discovery order in addition to his or her legal costs (although costs may not always be awarded to ISPs who are not fully successful in opposing the disclosure motion); and

(v) the public interests in favour of disclosure and protecting copyright must outweigh legitimate privacy concerns, which in the context of filesharing requires judicial caution to ensure that:

a. the applicant avoids delay between investigation and its request for information in order to minimize concerns relating to data reliability and to reduce the risk of exposure of innocent people to disclosure of their confidential information and to unjustified lawsuits; and

b. private information unrelated to copyright infringement is extracted before disclosure is made.

105 From a plaintiff's viewpoint, the equitable bill of discovery may well be preferable, since it can be pursued without the need to first initiate a legal proceeding. 
Privacy interests are entitled to further protection even where disclosure is ordered to ensure the order is narrowly drafted to specify exactly what information is to be disclosed and how it can be used. Confidentiality orders and orders requiring proceedings to be brought using only the initials of alleged infringers may also be necessary.

\section{THe DMCA, BMG ANd The QUest for ProcedurAl, JUSTICE}

\section{A. The Substance. of Procedure and the Procedure of Substance.}

The approaches to disclosure in RIAA and CRIA litigation serve as current reminders of the "entanglement of substance and procedure." $10 \%$ As Scott M. Matheson has noted:

To speak of procedural and substantive rules as if each can be defined independently of the other is inaccurate. Law is the product of the interaction between substance and procedure, but the relationship between the two is more sublle and complex than simply their joinder in litigation. ${ }^{107}$

The rules that we choose to define procedure affect substantive outcomes in very tangible ways. In the absence of a procedural mechanism for processing mass wrongs, for example, many individuals harmed will have no realistic opportunity to en force their rights and recover from wrongdoers for their injuries. ${ }^{10 x}$ Similarly, as made clear in the context of the CRIA and RIAA litigation, procedural laws relating to discovery between private parties can profoundly affect constitutionally entrenched rights, such as privacy. ${ }^{109}$ As the Supreme Court of Canada noted, with respect to compelled disclosure of the psychiatric records of plaintiffs in civil sexual assault litigation:

[T] he common law must develop in a way that reflects emerging Churter values.... One such valuc is the interest aflimed by s. 8 of the Charfer of each person in privacy. Another is the right of every person embodied in s. 15 of the Chorter to equal treatment and bencfit of the law. A rule of privilege which fails to protect confidential doctor/patient communications in the context of an action arising out of sexual assault perpetuates the disadvantage felt by victims of sexual assault, often women. The intimate nature of sexual assault heightens the privacy concerns of the victim and may increase, if automatic disclosure is the rule, the difliculty of obtaining redress for the wrong. 110

Though with less traumatic individual consequences than in the context to which the Supreme Court was speaking, the rules relating to disclosure in the CRIA and RIAA cases raise similar substantive issues - about copyright holders' ability to legally pursue infringers and the public and private interests at stake in online anonymity. These examples reaffirm

Solum, stypra note I at 215.

Scott M. Matheson. Jr., "Procedure in Public Person Defamation Cases: The Impact of the First Amendment" (1987) 66 Tcx. L. Rev. 215 at 223 [footnotes omitted].

For a comparative description of the development of procedures for class actions in Canada. sec Steven Penncy, "Mass Torts, Mass Culture: Canadian Mass Tort Law and Hollywood Narrative Jilm" (2004) 30 Queen's L.J. 205 at 214-24.

Equality, freedom of expression and privacy are protected, respectively, by ss. 15, 2(b) and 7 of the Canadian Charter of Rights and Freedoms, Part I of the Constitution Act, 1982, bcing Schedule B to the Canada Act 1982 (U.K.). 1982, c. 11 [Charter].

M. (A.) v: Ryan. [1997] 1 S.C.R. 157 at para. 30 [R!an]. 
the importance of designing procedure to honour substantive legal and constitutional commitments. "II

\section{B. Solum's Integrated APproach to Procedural. Justice}

Having recognized the depth of procedure's entanglement with substance Lawrence B. Solum, in "Procedural Justice," 112 puts forward an integrated approach that combincs and prioritizes numerous aspects of three predominant models of procedural justice. While agreeing that what he terms the utopian, ${ }^{113}$ balancing ${ }^{114}$ and participation ${ }^{115}$ models are each reflected in U.S. civil procedures, he argues that none is in and of itself sufficiently robust both to explain current procedure and to offer normatively satisfying justifications for it. Instead, he posits an integrated approach focusing on the two key principles of participation and accuracy, with participation the prioritized objective of procedural justice and each of the two principles subject to modification according to certain provisos. His approach can be summarized as follows:

(i) The Participation Principle - structure resolution of civil disputes to ensure meaningful participation for each interested party:

a. Interest Condition - extend rights of participation to all persons to be subject to a final and binding adjudication and to everyone else with a substantial interest in the matter to be determined;

b. Scope Condition - rights of participation should include, at minimum, advance notice to interested persons and an equal and meaningful opportunity to present evidence and arguments relevant to the dispute; and

In the U.S., the term "first amendment due process" has been used to describe judicial analysis of whether procedures (particularly in obscenily and defamation cases) show " the necessary sensitivity to freedom of expression" (Matheson, supra note 107 at 227 [footnote omitted], citing Freedman v. Maryland, 380 U.S. 51 at $58(1965)$ ).

Solum, supra note 1.

113 Solum associates the utopian model with writers such as Patrick Johnson "Civil Justice Reform: Juggling Between Politics and Perfection" (1994) 62 Fordham L. Rev. 833 and D.J. Galligan, Discretionary" Powers: A Legal Study of Official Discretion (Oxford: Clarendon Press, 1986). While Solum agrees that the civil justice system "strives for correcl outcomes," he notes that in many inslances the "search for truth" is compromised for considerations such as cost (Solum, ibid. at 244-45).

i1) Solum discusses two versions of the balancing model. Under the consequentialist approach, typified in the United States Supreme Court's decision in Mathews v. Eldridge, 424 U.S. 319 (1976), procedure is seen as being structured to balance accuracy and cost. Solum dismisses this approach for its insistence on trading of interests, without establishing a minimum level of protection for basic personal rights. Under the second approach, the focus is on ensuring that the costs imposed by the system of procedure are distributed fairly. In a system with great disparities in resources, Solum notcs that the costs of procedural error are not currently fairly distributed, since fair distribution across litigants depends heavily on social resources in a user-pay system. He argues that work of procedural justice should include halancing costs, not only in terms of accuracy, but in terms of preserving substantive rights (Solum. ibid. al 257-58).

11) The participation model focuses on the intrinsic value of procedure - not simply its instrumental value in achieving just substantive outcomes. Solum, in particular, focuses on participation as integral to treating citizens with dignity and respect. In this regard, he concludes:

The exercise of adjudicative power to bind an individual must be legitimate for the adjudication to be authoritative and, hence, to create content-independent obligations of political morality, to obey judicial decrees, and to respect the finality of judgments... [T] he legitimacy of adjudication depends on affording those who are to be bound a right to participate, either directly or through adequate representation (Solum, ibid. at 278-79). 
c. Impracticability - where notice or an opportunity to be heard is impracticable, provide interested persons with an adequate legal representative and structure the proceeding so the interests of the represented person are given full and fair consideration;

d. Fair Value of Procedural Justice Proviso - the fair value of basic liberties should be ensured, including the right to reasonable lawyer's fees in order to relieve against violation of those liberties;

(ii) The Accuracy Principle - structure legal proceedings to maximize the likelihood of reaching a legally correct outcome in each proceeding, departing from this principle only:

a. Substantive Rights - to ensure the process of adjudication does not unfairly infringe on substantive rights such as free expression and privacy;

b. Fair Distribution of Risk of Inaccurate Results - in order to ensure a fair distribution of the risks of inaccurate adjudication;

c. Systemic Accuracy - in order to maximize systemic accuracy, so long as procedures are announced in advance and can be complied with by making reasonable good faith efforts (or to maximize systemic accuracy insofar as it will not result in inaccuracy in individual cases); and

d. Costs of Adjudication - to ensure the costs of the process are not out of proportion with the interests at stake or the kind of proceeding. ${ }^{116}$

Solum's model provides a useful framework for considering the Canadian and U.S. online non-party disclosure cases from a procedural justice perspective. In turn, the Canadian and U.S. case studies offer interesting insights on the model itself.

\section{Procedural Justice in the OnLine Music Sharing Litigation}

The Canadian and U.S. approaches to non-party discovery amply support Solum's arguments relating to the entanglement of procedure and substance. Each approach also raises important concerns relating to Solum's key principles of participation and accuracy, although the concerns are certainly heightened under the expedited $D M C A$ approach.

\section{Procedure's ENTANGLement With SUbSTANCE}

Together, the American and Canadian approaches to disclosure of identifying information in online cases illustrate two of Solum's preliminary points. First, the procedures relating to non-party disclosure in these cases suggest potential examples of the way in which procedural law guides human conduct. In both cases the procedural possibility of obtaining identifying information from non-party ISPs (to the extent it is publicized) may well affect individual perceptions and activity online, as citizens are slowly awakened to the fact that the appearance of anonymity online is just that — an appearance. Whether, and if so exactly how, a widespread comprehension of this reality will affect online behaviour, the flourishing 
of Internet communication and the exercise of fundamental users' rights under current copyright legislation ${ }^{117}$ remains to be seen. ${ }^{118}$

Second, these case studies support Solum's assertions that procedural and substantive law are deeply entangled, as well as the centrality of participatory procedural mechanisms designed to achieve accurate substantive legal outcomes. In both the American and Canadian examples, the connection between the non-party disclosure procedures and substantive law and rights central to the public interest lie close to the surface during the preliminary process. At stake are substantive public interests ${ }^{119}$ in: (i) protecting citizens' abilities to legally pursue those who have harmed them, both online and offline; and (ii) protecting citizens' constitutionally enshrined rights to privacy. ${ }^{120}$ Without access to the identity of filesharers, copyright holders will not be able to enforce their legal rights, ${ }^{121}$ but access to identifying information profoundly affects substantive privacy rights. ${ }^{122}$ Since these rights must necessarily be balanced in order to determine whether identifying information should be disclosed, it is essential to understand their components and relative public values. ${ }^{123}$

As the FCA noted in $B M G / /$, there is a profound public interest in ensuring the creation and promulgation of ideas. ${ }^{124} \mathrm{~A}$ key component of the intellectual property strategy in Canada and in the U.S. has been to provide innovators with an economic "incentive to express their ideas in tangible form."12s Equally key to the public interest, but too often ignored, is limiting copyright holders' control over expression to avoid, as the Supreme Court of Canada has noted, "unduly limit[ing] the ability of the public domain to incorporate and embellish creative innovation in the long-term interests of society as a whole" and avoid

To the exlent, for example, that users are delerred from engaging in lilesharing on the basis of threatened litigation, they may effectively be deprived of their rights of fair dealing in relation to copyrighted material (Lawrence Lessig. Free Culure: How' Big Media Uses Technology and the L.aw fo Lock Down Culture and Control Creativity (New York: Penguin Press, 2004) at 195-96).

At least some statistics suggest that the threat of identification and litigation may be having RIAA's intended effect. RIAA initiated its U.S. litigation in early 2003. Between November 2003 and February 2004, an estimated 5 million fewer people were using the popular filesharing program KaZaa (Pew Study 1, supra note 27 at 2). From 3 February to 1 March 2004. 14 percent of fomer filesharers no longer download music, approximatcly $1 / 3$ of whom state the threat of litigation as their reason for stopping (Pew Study 1, ibid. at 1).

Here I use the word "public" quite deliberately. While the language of the FCTD and the FCA, and some of the American courts, oceasionally suggests that the public interest lies with disclosure and protecting copyright. privacy also represents a jointly shared and constitutionally enshrined public good. While we are rightly concemed about the individual implications of a privacy violation, we should be equally or more concemed about the broader ramifications of intrusions on privacy. For further discussion see Kerr \& Cameron, supra note 70.

120 Rights to free expression may also be jeopardized if anonymity and pseudonymity are unfairly compromised (Julie E. Cohen, "A Right to Read Anonymously: A Closer Look at 'Copyright Management" in Cyberspace" (1996) 28 Conn. L. Rev 981 ).

This statement presumes maintenance of the current regime for protecting the rights of copyright holders. Others have suggested that civil litigation and criminal prosecutions might be replaced with a levy that ensures rights holders are compensated, without the need to sacrifice online privacy and fredom of expression. Sec e.g. Neil Weinstock Netancl. "Impose a Noncommercial Use Levy to Allow Free Peer-to-Peer lijle Sharing" (2003) 17 Har. J.L. \& Tech. I.

12: BMG II. supra note 13 at paras. $1-4$.

133 Solum suggests that it may be appropriate to accord greater weight to rights such as privacy and free expression than to economic rights (supra note 1 at 258). 
obstacles to proper use of prior innovation. ${ }^{126}$ Part of the legislative strategy for avoiding undue limitation has been protection of users' rights, which are manifested in the Copyright Act provisions that limit the duration of copyright and ensure a right to fair dealing. ${ }^{127}$ Thus, when we speak of the public interest in protecting copyright holders' ability to enforce their legal rights, it is essential that we keep in mind the limited nature of those rights - as well as their primarily economic nature. ${ }^{128}$

Both levels of the Federal Court of Canada in $B M G$ and the California court in SeesCandy ${ }^{129}$ reflected on the other public interest at stake - privacy and anonymity on the Internet. In the Canadian context, the reasons in both $B M G I$ and $I$ focused on the need to protect the privacy of "innocent" Internet users. ${ }^{130}$ However, as will be discussed below, the bona fide threshold adopted by the FCA could unnecessarily expose many categories of "innocent" users to invasion of their privacy. If the U.S. experience is any indication, there will frequently be a difference between the Internet subscribers identified and those who actually engaged in filesharing. ${ }^{131}$ As a result, confidential information relating to "innocent" subscribers never engaged in filesharing is at risk of being revealed. Further, even where the subscriber and the filesharer are one and the same, the individuals whose identities are disclosed may well have been legitimately engaged in the exercise of their rights as users. ${ }^{132}$

In addition to individual Internet subscribers' privacy rights is the public interest in protecting privacy - an interest tied to the value of privacy in and of itself, rather than necessarily protecting "innocent" individuals. As Kerr and Cameron have noted:

[It is] crucial for the Court to recognize that ... [the] exercise [of its non-party disclosure power] does not merely involve weighing the privacy interests of the individual delendants against CRIA and the public interest in permitting parties to proced with lawsuits. There is a broader public interest in privacy that must also be considered. ${ }^{133}$

Both the public interests in enforcement of legal rights and privacy protection and in fostering citizens' respect for the law are engaged in this context. In the context of the power and resource imbalance between the music industry and the individual citizens the industry is targeting, ${ }^{134}$ public procedural thresholds should be fixed to minimize their use to reinforce

Theberge v. Galerie d'Art du Petit Champlain, [2002] 2 S.C.R. 336, 2002 SCC 34 at paras. 30-32 [Théberge]. Copyright Act, R.S.C. 1985, c. C-42, ss. 6, 7(1), 10(1), 29-29.2, 30-32, as am.

As the Supreme Court of Canada said in Theberge, copyright is primarily an economic right in Canada (supra note 126 at para. 12).

SeesCandy, supra note 46; BMG II, supra note 13 at para. 38 (where the FCA stated, "[p]rivacy rights are significant and they must be protected.").

$B M G$ I, supra note 13 at para. 42; BMG $I$, supra note 12 at paras. $21,43$.

Knopper, supra note 15.

$B M G I$, supra note 13 at paras. 24-26; $B M G /$, supra note 12 at paras. 49-50.

Kerr \& Cameron, supra note 70 at 19 [emphasis in original].

For articles discussing the industry's targeting of students, see: von Lohmann, supra note 25; RIAA, News Release, "RIAA Expands Scope Of Illegal File-Sharing Lawsuits Against Student Abusers Of" Internet2" (26 May 2005), online: RIAA <www.riaa.com/news/newsletter/052605.asp>. For an article on a grandparent being subpocnaed, see EFF 24 September 2003, stupra note 25. See also Letter from Senator Norm Coleman to Cary Sherman, President of RLAA (31 July 2003), online: Berkeley Intellectual Property Weblog <ht1p:/joumalism.berkeley.edu/projects/biplog/archive/000961.html $>$ in which he writes: 
the dominant position of those with greater economic resources at the expense of those with fewer resources and the public at large. ${ }^{135}$ Non-party disclosure in the online music sharing cases, therefore, should reflect a contextual analysis and balancing of public interests including not only enforcing legal rights and protecting privacy, but also in creating reasons for less-empowered individuals to respect the law and its processes.

\section{The Participation Principle:}

Solum suggests that the resolution of civil disputes ought to be structured to ensure meaningful participation by "interested persons," which he defines to include everyone with a substantial interest in or who will be bound by a final and binding adjudication. ${ }^{136}$ Meaningful participation would include, at least, advance notice to interested persons and an equal and meaningful opportunity to present relevant evidence and arguments. Where notice or direct participation by interested persons is impractical, Solum suggests the proceeding should be structured to ensure adequate representation that would facilitate full and fair consideration of their interests. ${ }^{137}$

\section{a. Approach under Section 512(h) of the DMCA}

Section $512(\mathrm{~h})$ of the $D M C A$ provides no opportunity for advance notice, direct participation by interested parties or for their representation. Under $5.512(h)$ the privacy and free speech rights of subscribers have depended upon after-the-fact ISP challenges to issued subpoenas. While Verizon and other ISPs did eventually initiate such challenges, many other ISPs complied with s. 512 (h) subpoenas without question. ${ }^{138}$ The provision therefore violates Solum's first and primary principle of procedural justice - participation. As he argues, this may have consequences not only in terms of the accuracy of the ultimate legal outcome (as discussed in detail below), but also in terms of public respect for the administration of justice:

The exercise of adjudicative power to bind an individual must be legitimate for the adjudication to be authoritative and, hence, to create content-independent obligations of political morality, to obey judicial decrees, and to respect the finality of judgments....

[ T] he legitimacy of adjudication depends on affording those who are to be bound a right to participate, either directly or through adequate representation. ${ }^{139}$

The RIAA subpoenas have snared unsuspecting grandparents whose grandchildren have used their personal computers, individuals whose roommates have shared their computers, as well as colleges and universities across the United States like Boston College. DePaul University and the Massachusetts Institute of Technology. Individuals like Bob Barnes, a grandfather from Fresno, California, are not immune from devastating financial [losses]. Mr. Barnes is facing \$45 million in penalties for downloading some of his "oldie" favorites.

of course, this is reflective of a larger problem in the Canadian legal system. As Solum notes, without adequate public funding for litigants, those with fewer resources bear a greater risk of a substantively incorrect legal outcome (Solum, supra note 1 at 258).

Ibid. at 305.

Ibid. at 309-10.

Rein, supra note 14.

Solum, supra note $l$ at 278-79. 


\section{b. Approach under Canadian and U.S. Rules of Court}

The Canadian and U.S. approaches pursuant to each jurisdiction's respective federal court rules much more adequately address the participation principle than does s. $512(\mathrm{~h})$ of the $D M C A$. The benefits of participation are more complex in the music-sharing context where one of the key public interests at stake is privacy through anonymity. In this context, one of the key procedural objectives is to protect against unjustified invasions of privacy by limiting the situations in which identifying information relating to subscribers will be revealed. The very purpose of the procedural step is to ascertain the identity of the alleged wrongdoer - information without which it is difficult for the plaintiff to provide notice and an opportunity to participate.

The impracticality of providing notice and allowing participation, therefore, has forced the Canadian and U.S. approaches under their respective rules of discovery toward representation of the interests of the parties not present. In $B M G$, Solum's proviso was arguably satisfied by the participation of the public interest interveners Canadian Internet Policy and Public Interest Clinic and Electronic Frontier Canada and also to some extent by the ISPs involved. ${ }^{140}$ While the public interest interveners did not appear as the legal representatives of individual subscribers, they were instrumental in bringing forward arguments as to the privacy interests at stake, as well as the potential defences to alleged infringement. ${ }^{141}$ As a result, we now have in Canada a firm Federal Court precedent that requires privacy interests to be taken into account on a non-party disclosure motion.

At least one other reported Canadian precedent expressly referred to the need to protect anonymity on the Internet in the context of a non-party disclosure motion relating to an alleged defamation. ${ }^{142}$ Moreover, the "equitable bill of discovery" cases anticipated the need to take into account private interests weighing against disclosure. ${ }^{143}$ However, in many (if not most) cases, no one appeared to oppose the disclosure motions or to make representations about the privacy interests weighing against disclosure. ${ }^{144}$ Moreover, observation of privacy interests relating to disclosure of identities does not necessarily flow obviously from the plain text of r. 238 of the FCR. ${ }^{145}$

While the $B M G$ precedent will undoubtedly be helpful in terms of ensuring that the general public interest in privacy is taken into account in relation to identity disclosure orders, there currently appears to be no mechanism to ensure that privacy interests will be adequately represented. An adversarial system such as Canada's depends on a contest of self-

However, as Kerr and Cameron argue, there are sound reasons to question whether ISPs can and should be relied upon to represent and protect the interests of their subscribers in these kind of proceedings (supra note 70 at 21-22).

Ibid. at $11-12$.

14: In Invin Toy, supra note 69, the Court was applying r. 30.10 and 31.10 of the Ontario Rules of Civil Procedure R.R.O. 1990, Reg. 194, as am., relating to documentary and oral discovery. Although no one appeared to contest the motion for disclosure of a subscriber's identily in connection with a detamation action, the Court appeass, of its own motion, to have taken into account the public interest in preserving anonymity on the Intemet. 
interested parties to advance the full panoply of arguments for adjudication by the court. ${ }^{146}$ In the context of online communications, some ISPs view themselves as having no particular alignment either with the interests of their subscribers or those of copyright owners. ${ }^{147}$ As a result, there are sound reasons to be concerned about whether those in charge of private information will even bother to appear to contest its disclosure, let alone fully represent the public interest in privacy. If ISPs cannot be relied upon or expected to appear to represent the interests of subscribers, we have little comfort that the procedural justice prerequisite of participation by interested parties (or at least representation of their interests) will be consistently satisfied.

Thus, neither the Canadian nor the U.S. judicially based procedures for obtaining nonparty disclosure necessarily builds in participation for, or representation of, the interests of those most directly affected by a disclosure order. While in some circumstances it might be possible to characterize a disclosure order as merely "preliminary," rather than final and binding, because subscribers will still have the opportunity to contest the allegations against them, a disclosure order is final and binding in terms of subscriber privacy. Once subscriber identity is revealed, the result - in terms of their privacy - is final. ${ }^{1+8}$ The threshold test set out by the FCA in $B M G / I$ obviously requires that the general public interest in privacy be taken into account, but protection of individuated privacy interests ${ }^{149}$ and a mechanism for ensuring notice to, and representation of, subscribers should be considered. Advancing the procedural justice interest in notice and representation without compromising the substantive end of privacy might in this context be better addressed by requiring:

(i) where possible, that ISPs advise a subscriber when they are notified of a request for disclosure pertaining to that individual;: ${ }^{50}$ and

(ii) formulation of mechanisms that allow for legal representation of subscribers without compromising their anonymity or to ensure that, at minimum, an amicus curiae is appointed to advance relevant privacy arguments during disclosure motions.

The Canadian and U.S. non-party disclosure procedures under their respective federal rules of court better advance the procedural justice prerequisite of participation by interested parties than does s. $512(\mathrm{~h})$ of the DMCA. Notwithstanding this, the procedure in Canada still leaves open the possibility of inadequate representation of public and personal interests in privacy. Moreover, the bona fide threshold adopted in $B M G / /$ and under s. $512(\mathrm{~h})$ is

Neil Brooks. "The Judge and the Adversary System" in A. Linden, ed., The Canadian Judiciary (Toronto: Osgoode Hall Law School, 1976) at 90-91.

Kerr \& Cameron, supra notc 70 at 20-21.

As L'Heureux-Dubé J., dissenting, stalled in Ryom, stupra note 110 at para. 93, "onec breached, privacy cannot be regained."

There may, for example, be individual situations in which a particular subscriber's reasonable expectation of privacy is heightened, such thut consideration of their specilic circunstunces would be exsential to a proper balancing of inlerests.

Ironically, Bill C-60 would require ISP's to serve notice of alleged infringement on their subscribers, when notice of an alleged violation is served on the ISP. However, the Bill would also require ISP's to maintain potentially highly personal and confidential data for at least six months following receipt of notice from a copyright holder - thereby creating a cache of identifying information that may not have been maintained by the ISP in the past (Bill C-60, supra note 7, cl. 29). 
arguably inconsistent with procedural justice in terms of its potential inconsistency with Solum's accuracy principle.

\section{The ACCURACY PRINCIPLE}

Solum suggests that one aspect of procedural justice is that legal proceedings be structured to maximize the prospect of reaching a substantively correct legal outcome in each individual case. ${ }^{|5|}$ Solum's theory of procedural justice would allow for deviation from that principle in order to: (i) ensure the adjudication process does not unfairly infringe substantive rights; (ii) ensure a fair distribution of the risks of an inaccurate outcome; (iii) maximize systemic accuracy (so long as procedures are announced in advance and can be complied with through reasonable good faith efforts); or (jv) ensure the costs of the procedure are not out of proportion with the interests at stake. ${ }^{152}$

With respect to the trade-offs between accuracy and substantive rights in the discovery process, Solum notes:

[L]iberal discovery may operale to increase aceuracy, but it also imposes burdens on both litigants and third parties. A rights-based approach would attend to the question whether discovery would violate the preexisting moral or legal rights of the parties, such as the right to privacy. Rather than balancing the costs of privacy invasions against the benelits in terms of increased accuracy, a rights-based conception might look to whether the privacy right has been waived, and if not, whether that right is more fundamental (or ranked higher in a lexical ordering) than the interests of the parties in accurate adjudication. ${ }^{153}$

The Canadian procedure under $B M G I I$ and the U.S. procedure under s. 512(h) of the $D M C A^{154}$ provide useful examples of the potential disconnect between liberal discovery rules and achieving substantively accurate legal outcomes. As between the two approaches, the Canadian procedure under BMG // better satisfies Solum's provisos relating to limiting discovery than does the procedure under s. 512(h). In adopting a bona fide belief threshold for ordering disclosure both approaches provide less than optimal protection in terms of accuracy of result, the substantive right of privacy and fair distribution of the risks of inaccurate outcomes. However, the caveats and protections built into the test articulated in $B M G I I$ provide greater protections without imposing undue costs than does s. $512(\mathrm{~h})$.

Solum, supra note I at 311.

Ihid. at 312-13.

Ibid. at 258-59.

As noted above in Part II, there are also instances in which U.S. courts have ruled that only a "good faith" or bona fide, rather than a prima facie, threshold need be satisfied in order to obtain non-party disclosure of identifying information (stpra note 50). 


\section{a. The Liberal Discovery/Accuracy in Outcome Disconnect}

The Canadian and U.S. experiences with respect to disclosure in the online music sharing cases raise an important point relating to accuracy in outcomes - more disclosure is not necessarily positively associated with achieving a substantively accurate legal outcome. Solum recognizes this in stating that liberal rules of discovery "may operate to increase accuracy" 155 - but accuracy in what sense? Given the Canadian reality that some 95 percent of civil cases settle without a trial, ${ }^{156}$ it is essential to recognize that procedural rules relating to discovery may in fact, promote situations in which there is no final judicial determination. ${ }^{157}$ We may view this as consistent with the public interest if the reason for settlement (or discontinuance) reflects the fact that full rights of discovery have enabled the parties to rationally evaluate the substantive merits of their respective positions.

On the other hand, there may be situations in which liberal rights of discovery avert final adjudication for reasons inconsistent with achieving substantively accurate legal outcomes. For example, if the scope of discovery is unduly broad, litigants may settle in order to avoid oppressive costs, rather than due to any evaluation of the merits of their legal position in the case. ${ }^{158}$ In the case of liberal rules relating to disclosure of identifying information in an otherwise anonymous context (such as the online music sharing cases) or involving other private or highly personal details (such as in civil sexual assault cases), litigants might settle in order to avoid embarrassment or further delving into private aspects of their lives. ${ }^{159}$ In these kinds of situations, fuller rights of discovery will not necessarily correspond with achieving substantive accuracy (either in adjudicated results or in final outcomes reflected in out-of-court settlements).

The $B M G / /$ approach addresses this concern in part by requiring the music industry to provide complete and current first-hand evidence about alleged filesharing and filesharers.

Solum, supra note 1 at 258 [emphasis added].

Ontario, Ministry of the Attoncy General, Ontario Civil Justice Review, First Report (Toronto: March 1995) c. 13.1, online: Ministry of the Attomey General <www.attomeygeneral.jus.gov.on.ca/english/

about/pubs/cjt/firstreport/management.asp>.

Some would argue that one of the key objectives underlying liberal rules of discovery is to promote settlement. Sec Ontario. Ministry of the Altomey General, Ontario Civil Sustice Review. Supplemental and Final Report (Toronto: November 1996) c. 6.5, online: Ministry of the Attorney General <www. attomeygeneral.jus.gov.on.ca/english/abouv/pubs/cjr/suppreport/ch65a.asp>.

For an understanding of the financial costs associated with the discovery phase, see Onturio Civil Justice Review, First Report, supra note 156, c. 14, online: Ministry of the Attomey General <www.attomeygeneral. jus.gov.on.ca/english/about/pubs/cjr/lirstrepor/rules.asp>.

Justice L'Heureux-Dubé, in the context of civil sexual assault litigation, stated in her dissent:

Given this context, the traditional approach to discovery, the one where the plaintiff must rely upon the ad hoc protection privilege provides, will serve as a strong disincentive to plaintiffs to attempt to recover compensation for the injury caused. The mutual exchange of information for the shared purpuse of expediting the search for justice is turned into a process which may prevent a plaintiff from seeking compensation in the courts or may encourage a premature and unfair settlement to avoid excessive disclosure of the privale documents. Such a result cannot comport with our sense of justice, particularly as it is informed by the Charter values of privacy and equality. Clearly, a more predictable procedure is in order, onc which addresses the unique difficultics faced by plaintiffs in these circumstances (Ryan, supra note 110 at para. 92).

See also Jane Doe, The Story of Jane Doe: A Book About Rupe (Toronto: Random House Canada, 2003); June Ross, "Partial Privilege and Full Disclosure in Civil Actions: M(A) v. Ryan," Case Comment (1997) 35 Alta. L. Rev. 1067. 
The FCA suggested that these exacting standards of proof are necessary in order to reduce the risk of violating the privacy rights of "innocent persons." 160 The evidence before the Court demonstrated that the older the information relating to alleged filesharing and associated IP addresses, the greater the risk of inaccuracy in the identities disclosed. ${ }^{161}$ Through establishment of these procedural requirements, the FCA addressed the concern that disclosure could lead to privacy violations unrelated to accuracy in final outcomes, in that the identities revealed might not be those of persons who had engaged in infringing activity. ${ }^{162}$

However, the FCA's approach addresses only part of the concern with respect to the potential disconnect between disclosure and substantive accuracy in outcomes. Even if firsthand, current and complete evidence is filed, identity disclosure may not be related to accuracy in terms of final outcomes. The adoption of the bona fide belief standard by the FCA does not require plaintiffs to provide evidence supporting the elements of a prima facie valid copyright infringement claim. ${ }^{163}$ Even if only the identity of individuals engaged (or associated in some way with those engaged) in online music sharing is disclosed, in the absence of a substantive analysis of the validity of the legal claim advanced, we may never learn whether the music sharing in question does, in fact, constitute infringement. ${ }^{16+1}$ As a result, privacy is compromised with no necessary connection to substantive accuracy individuals' anonymity may be compromised even where they did not engage in any substantive legal wrong.

The disconnect between disclosure and accuracy in legal outcomes is further exacerbated in the online music sharing cases, when one considers contextual factors likely to lead to settlement - regardless of the substantive merits of the legal claim advanced. Settlements in this context deprive both the individual in question and the public at large from an accurate adjudication of the substantive merits of the claims advanced by the music industry. Some may argue that consideration of the impact of procedural decisions on substantive outcomes ousside of legal adjudication exceeds what can and should be expected in terms of procedural justice. ${ }^{\text {tos }}$ Perhaps the best that we can expect of our legal procedures in terms of accuracy is that they will be structured to ensure accuracy in final adjudicated results. ${ }^{166}$ While there may be reasons for accepting such a limited vision in terms of advancing systemic justice, there are sound reasons in individual cases (or categories of cases) to question it.

BMG II, stupra note 13 at para. 43.

Ibid.

In fact, as noted above in Part IV.C, many of the identities disclosed will not be those of filesharers or infringers, since one person may subscribe for the service, but others may use it, or certain filesharing activity may, in fact, be legal.

BMG II, siupra note 13 at para. 42.

II, for exumple, uploading and downloading are legal in Canada by virtue of the Canadian law relating to authorizing and the private copying levy (BMC 1, supros note 13 at paras. 24-26).

Some would argue that public interference in private resolution of disputes deprives individuals of their fundamental freedom of contract. See Michael Abramowicz, "On the Alienability of Legal Claims" (2005) 114 Yale L.J. 697.

In fact, this is what Solum suggesting - that one kcy goal of procedural justice is to achieve substantively accurate adjudication of legal outcomes (supra note 1 at 320 ). 
Where, as in the online music sharing cases, experience suggests substantive adjudication may be unlikely after identity disclosure, ${ }^{167}$ and there are sound reasons for concern that private settlements reached relate more to a party's inability to withstand the costs of litigation than to an assessment of the validity of their substantive legal positions, procedural justice depends on establishment of a threshold for discovery reflecting that contextual reality. Several factors in the online music sharing context coalesce in a way that exaggerates the risk that individuals will pay to settle disputes for reasons other than a solid evaluation of the substantive merit of their cases:

(i) the scope and application of many users' rights are sufficiently amorphous as to make it difficult to evaluate in advance their availability and viability as defences; ${ }^{1 \text { hk }}$

(ii) the maximum statutory penalties for infringement are high, even though the actual damage occasioned is likely to be negligible; ${ }^{169}$

(iii) in virtually all cases, CRIA will be better financed to withstand the cost of litigating and will stand to gain more by litigating to prove a point than will the average individual defendant; ${ }^{170}$

(iv) if the U.S. situation is any example, CRIA is likely to be willing to settle with each defendant for considerably less than the potential statutory maximum penalty, although the amounts are likely to be significant to the individuals involved;"11

(v) individual defendants are likely to be less motivated than CRIA to incur the costs of adjudication in order to set a precedent, since CRIA may be able to use favourable precedents in litigation against others, while individual defendants are unlikely to have the resources to fund precedent-setting litigation on principle; ${ }^{172}$ and

Knopper, supra note 15.

Lessig. supra note 116 , makes a compelling argument about the degree of uncertainty with respect to the parameters of copyright negatively affecting creativity and innovation. The differences between the FCTD and FCA in relation to the substantive law in $B M G J$, supra note 13 at paras. 33-34, and $B M G G I$. supra note 13 at paras. 51-52, also speak to a lack of clarity in terms of user and rightsholder entitlements. The lack of clarity in the copyright context provides a useful example of two problems that Solum notes permeate civil litigation - "imperfect knowledge of law and fact" and "the problem of incomplete specification of legal norms" (supra note 1 at 320 ).

Under the Copyright $A c t$, statutory damages can be as high as $\$ 20,000$ for eivil liability in copyright infringement (Copyright Act, supra note 126, s. 38.1).

Assuming that CRIA intends to follow the lead of RIAA, it will market their "sucecss" in litigation heavily, with the potential effecl of deterring lurther filesharing, but perhaps also deterring pursuit of legal defences.

Knopper, supra note 15.

The inequality in this son of "David and Goliath" litigation resembles, in some ways, the situation for individuals pursuing mass wrongs prior to more liberal rules allowing joinder of claims and class actions. It is interesting to consider whether in future individual defendants in online music sharing litigation would qualify for and ultimately benefit from being certified as a defendant class under relevant class proceedings legislation. See e.g. Class Proceedings Act. 1992, S.O. 1992, c. 6, ss. 3-4. Class Proceedings Act, R.S.B.C. 1996, c. 50, s. 3 and FCR, supra note 64, r. 299.1 S. which permit certification of a class of defendants. 
(vi) the potential for other embarrassing private details to be made public if the release of information from ISPs reveals anything more than the absolute bare minimum details as to the subscribers' identity. ${ }^{173}$

In this context, more disclosure or more easily obtained disclosure is not necessarily connected with substantive accuracy in legal outcomes. Establishing a bona fide belief threshold may drive toward substantively accurate outcomes in some circumstances, but it shifts the risk of substantive inaccuracy more heavily onto the shoulders of those least able to bear that risk. In so doing, it could unnecessarily titt the balance against substantively accurate legal outcomes.

\section{b. Substantive Rights, Risks of Inaccurate Results and Costs}

The bona fide belief threshold adopted in both $B M G I /$ and s. $512(\mathrm{~h})$ also appears less than optimal in terms of protecting substantive rights, since the privacy interests of numerous subscribers who are not filesharers and of subscribers engaged in legal filesharing will inevitably be compromised. The lower threshold, in this sense, runs contrary to Solum's suggestions in terms of procedural justice - that is, that one might invoke higher thresholds of proof to protect higher order values, such as privacy, from being compromised in favour of lower order values, such as economic interests. ${ }^{174}$ Further, the test arguably fails to fairly distribute the risk of inaccurate results. By making disclosure easier for the better financed music industry to obtain, the test would appear to exacerbate the already unequal distribution of risk that Solum notes arises in civil proceedings as a result of inadequate funding for many interested parties. ${ }^{175}$

However, there are important points of departure between the $B M G / /$ and s. 512(h) approaches. The $B M G I /$ approach better protects privacy interests than does s. 512(h) by imposing more exacting standards of proof on discovery-seekers. Specifically, those seeking disclosure will have to provide current, complete first-hand evidence, and may be faced with confidentiality orders to protect against public disclosure of subscriber identity, as well as orders requiring very specific and minimal levels of disclosure. ${ }^{176}$

Neither the Canadian nor either of the U.S. approaches necessarily comport with Solum's lexicon for establishing process that best promotes procedural justice. The Canadian approach under $B M G$ affords greater opportunities for advance notice to and representation of the interests of affected parties, as well as greater protections for substantive rights and fairer distribution of the risk of inaccurate results than does s. 512(h). Preferable to both of these approaches, however, may be that of certain U.S. courts under the FRCP, requiring

The FCA refers to the risk of disclosure of irrelevant private information in $B M G H$, supra tole 13 at para. 44.

Solum, supra note 1 at 312.

Ibid. at 258. The impact of one party being better financed than the other may be mitigated to some extent in Canada through a cost system that generally requires the losing pany to pay a portion of the legal fees of the successful pary. However, the mitigating impact of that cost system is only partial given that the levels of indemnity generally fall far short of the actual costs incurred in litigation (Garry D. Watson et al, eds., The Civil Litigation Process: Cases and Materials, Sth ed: (Toronto: Emond Montgomery, 1999) at 363, 375-76).

Levinsohn, supra note 45 at 251-52, 264. 
disclosure seckers to demonstrate a prima facie case in order to obtain identifying information. ${ }^{17}$ Any additional cost to the music industry associated with application of this higher standard can be justified as proportionate with the privacy right at stake and the public interest in achieving accurate substantive outcomes.

\section{Conclusion}

The non-party disclosure motions in the Canadian and U.S. online music sharing litigation starkly reveal procedure's intimate connection with substance and the importance of procedure to achieving substantively just legal outcomes. The administrative mechanism made available in $\mathrm{s} .512(\mathrm{~h})$ of the $D M C A$ is the least consistent with achieving procedural justice. Disclosure ordered without participation by or representation of the privacy interests at stake in the context of the power and economic imbalance between the disputants in this area could well tip the balance in favour of substantively inaccurate outcomes.

While the Canadian approach in $B M G / /$ provides greater opportunities for representation of the public interests at stake beyond the enforcement of copyright, adoption of the bones fide belief standard in this context may well lead to settled outcomes unrelated to the substantively correct legal positions of the parties. Moreover, the Court risks its procedures being used as a tool to exacerbate existing inequalities in resources between the music industry and those against whom they seek to make claims.

Context-specific procedures, such as adoption of a stricter prima facie case threshold for disclosure adopted in certain U.S. decisions under the U.S. FRCP, may therefore be preferable in terms of promoting legally correct outcomes, balancing the substantive rights at stake (taking into account the current imbalance between the disputants) and more fairly distributing the risk of inaccurate substantive outcomes.

The Canadian government, thus far, has chosen not to propose measures that would ease the threshold for obtaining disclosure of identifying information in the online music sharing context. If anything, achieving procedural justice may require the government to consider whether additional measures are necessary to impose a threshold higher than the one established by the FCA in $B M G / I$. If citizens understand that their rights to privacy will be properly weighed against the economic interests of music industry in making decisions about disclosure, a step may be taken toward providing them with a "principled reason to respect the outcomes of civil process." 